\title{
Tài trọ̣ có làm gia tăng tầm ảnh hưởng của nghiên cứu?
}

Nghiên cứu khoa học luôn đóng vai trò quan trọng trong việc thúc đẩy sự phát triển kinh tế và xã hội của các quốc gia và thế giới $[1,2]$. Tuy nhiên cùng với sự gia tăng về chi phí nghiên cứu và khan hiếm các nguồn lực kinh tế, quá trình tài trợ ngày càng được chính phủ và các tổ chức xem xét một cách thận trọng để đảm bảo tính hiệu quả của các khoản đầu tư nghiên cứu [3]. Mới đây, nghiên cứu "Is funding related to higher research impact? Exploring its relationship and the mediating role of collaboration in several disciplines" được thực hiện bởi Belén Álvarez-Bornstein và María Bordon đã hé lộ mối liên hệ giữa khoản tài trợ và tầm ảnh hưởng của các nghiên cứu [4].

Nghiên cứu đã tiến hành phân tích dữ liệu các công bố khoa học trong thời gian 5 năm (2010-2014) của các nhà nghiên cứu Tây Ban Nha thuộc lĩnh vực nghiên cứu khác nhau, trích xuất từ cơ sở dữ liệu của Web of Science (Clarivate Analytics) cùng các thông tin về tài trợ, cộng tác và chỉ số ảnh hưởng. Dựa trên các tiêu chuẩn như sự tách biệt về tri thức, mô hình cộng tác và tương đương về quy mô công bố, các tác giả đã lọc ra 7 lĩnh vực bao gồm: Bảo tồn đa dạng sinh học (Biodiversity Conservation); Virus học (Virology); Hệ thống tim mạch (Cardiovascular System); Khoa học Vật liệu Polime (Polymer Sciences); Viễn thông (Telecommunications); Thống kê và Xác Suất (Statistics \& Probability); Quang phổ học (Spectroscopy) để đưa vào phân tích và so sánh.

Kết quả cho thấy các nghiên cứu được tài trợ thì thường được xuất bản trên các tạp chí có mức uy tín cao hơn, có xu hướng nhận được tỷ lệ trích dẫn cao hơn khi so sánh với các nghiên cứu không nhận tài trợ. Mối liên hệ tích cực giữa tài trợ và tầm ảnh hưởng của nghiên cứu này được tìm thấy ở cả bảy lĩnh vực, kể cả khi có sự khác biệt về mô hình sản xuất tri thức

Giống như các nghiên cứu trước đó về đề tài này, các tác giả cũng tìm thấy mối liên hệ giữa việc tài trợ và mô hình cộng tác. Trong đó, các nghiên cứu được tài trợ thường có sự tham gia và hợp tác của nhiều tác giả hơn. Điều này được cho là có sự khuyến khích từ các tổ chức tài trợ theo một giả định rằng sự cộng tác sẽ đem lại nhưng thành quả tốt hơn và tránh những trùng lặp trong các nỗ lực nghiên cứu. Mặt khác, nguồn kinh tế từ tài trợ cũng cho phép các nhà nghiên cứu hợp tác/kết nạp (có hợp đồng,..) các học giả có chuyên môn khác hoặc mở rộng mạng lưới xã hội của 
họ thông qua việc gia tăng di chuyển (như tham dự hội thảo, ngoại trú tại các trung tâm nghiên cứu nước ngoài,...).

Tuy nhiên, sự tác động của việc tài trợ đến số lượng nghiên-cứu-có-sự-cộng-tác-giữa-nhiều-tổ-chức (hợp tác ngoài tổ chức) được tìm thấy là không có sự khác biệt có ý nghĩa thống kê giữa nghiên-cứu-có-tài-trợ và nghiên-cứu-không-được-tài -trợ ở 4/7 lĩnh vực. Có vẻ như việc hợp tác bên ngoài tổ chức đòi hỏi nhiều chi phí về hệ thống và nỗ lực điều phối hơn là hợp tác nội bộ. Tác giả gợi mở rằng điều này cần được xem xét và phân tích kỹ hơn vì nó có liên quan đến yêu cầu từ các chính sách tài trợ.

Mặt khác, sự tác động tích cực giữa việc tài trợ đến sự hợp tác quốc tế được tìm thấy có ý nghĩa thống kê trong 3 lĩnh vực (Bảo tồn đa dạng sinh học, hệ thống tim mạch, virus học). Kết quả này liên quan đến việc các chuyên ngành trên là những những ngành có mạng lưới kết nối rộng lớn nhất - điều vốn phụ thuộc nhiều vào những thỏa thuận chính thức và sự hỗ trợ về kinh tế.

Nghiên cứu cũng khám phá mối liên hệ giữa nguồn kinh tế tài trợ và mức trích dẫn cao (trên mức trích dẫn của các bài công bố đồng thời xem xét các biến số như số lượng tài liệu tham khảo, phân loại phần tư của tạp chí và phạm vi cộng tác. Theo phân tích, ba biến số trên có nhiều ý nghĩa giải thích cho tỷ lệ trích dẫn cao trên mức trung bình trong tất cả các lĩnh vực, trong khi việc tài trợ chỉ có ý nghĩa giải thích đáng kể trong bốn lĩnh vực. Tuy nhiên, phân tích biến trung gian cho thấy việc tài trợ có tác động gián tiếp đến tỉ lệ trích dẫn thông qua 3 biến số lượng tài liệu tham khảo (trong bốn lĩnh vực), phân loại phần tư của tạp chí (tất cả các lĩnh vực) và phạm vi cộng tác (trong ba lĩnh vực). Vậy nên, nếu chỉ xem xét tác động trực tiếp của việc tài trợ đến mức độ tác động khá thấp, tuy nhiên cùng với các tác động giản tiếp qua các biến trung gian cho thấy việc tài trợ có tác động lớn đối với tỉ lệ trích dẫn của các bài công bố. Và đây cũng là chỉ số cho thấy tầm ảnh hưởng của nghiên cứu

Nhìn chung, các bằng chứng từ nghiên cứu của Belén Álvarez-Bornstein và María Bordon đã cho thấy tài trợ đóng vai trò hiệu quả trong việc nâng cao mức ảnh hưởng của nghiên cứu, giảm thiểu các bài báo không được trích dẫn và thúc đẩy sự hợp tác. Từ đó, nghiên cứu cũng cung cấp cho các nhà hoạch định chính sách, và nhà tài trợ một góc nhìn để quản lý nghiên cứu và tối ưu hóa lợi nhuận các khoản kinh phí. 
Phương Thục

\section{Tài liệu tham khảo}

[1] Phạm Minh Chính \& Vương Quân Hoàng. (2009). Kinh tế Việt Nam: Thăng trầm và đột phá. Nxb Chính trị Quốc gia, Hà Nội.

[2] Phạm Minh Chính \& Vương Quân Hoàng. (2008). Bối cảnh tài chính Việt Nam 1997-1998 và 2007-2008: Khoảng cách và biến đối. Nghiên cứu Kinh tế, 48(7), 3-24.

[3] Vuong, Q. H. (2018). The (ir) rational consideration of the cost of science in transition economies. Nature Human Behaviour 2 (1), 5, doi: 10.1038/s41562-017-0281-4.

[4] Álvarez-Bornstein, B., \& Bordons, M. Is funding related to higher research impact? Exploring its relationship and the mediating role of collaboration in several disciplines. Journal of Informetrics, 15(1), 101102, doi: 10.1016/j.joi.2020.101102 